\title{
Prospects of electric heating applying in Russian cities to ensure their sustainable development
}

\author{
Roman Okorokov ${ }^{1, *}$ and Anna Timofeeva ${ }^{1}$ \\ ${ }^{1}$ Peter the Great St.Petersburg Polytechnic University, Polytechnicheskaya, 29, 195251, \\ St. Petersburg, Russia
}

\begin{abstract}
One of the stable trends in development of the world electric power industry is the transition from monotony to diversity in its evolution. It is characterized by a wide range of the strategic tasks solved by a set of the used energy resources and a changing spectrum of the possible energy technologies. However in the thermal energy supply of consumers in Russia for almost 100 years there is practically the only system of water heat supply that does not meet modern ecological, anthropogenic, technological and social requirements which motivated authors to conduct research on the alternative system of electrical heating. Materials for the study of the two heat supply systems were the actual parameters of alternative systems and their implication in technological and economic spheres as well as the impact on environmental indicators. Research methods include system approach, analysis of statistical data and authors' estimates. Result of comparing of the two alternative heat supply system is the classification of their positive and negative factors at the qualitative and quantitative levels of assessment. The conducted research has shown the significant advantages of the new electric heat supply system which is more in line with the requirements of sustainable development of Russian cities, preserves health and improves quality of life of their inhabitants.
\end{abstract}

\section{Introduction}

At present time the new stable trend has emerged in development of the world electric power industry. It can be defined as a strategy for transition from monotony to diversity not only in the traditional quantitative but, above all, qualitative understanding of this word. On the one hand, the diversity of development of the world electric power industry is understood as a growing set of strategic objectives required implementation, on the other hand, a wide variety of possible energy resources and a constantly changing range of new energy technologies to meet humanity's energy needs.

The objective reasons for the transition from monotony to diversity of development of the world electric power industry and the energy technologies of individual countries are the changes of many factors that are clearly manifested in the world economy in recent

\footnotetext{
${ }^{*}$ Corresponding author: roman okorokov@spbstu.ru
} 
years. These factors include the following types: natural, environmental, anthropogenic, technological and social.

The natural and environmental changes are evident in the accelerated rise of the Earth's temperature increased by $0.6{ }^{\circ} \mathrm{C}$ between 1990 and 2000 according to the World Meteorological Organization [1]. Such temperature increase was achieved previously in 100 years. According to experts, the significant role in the growth of the Earth's temperature is played by the products of combustion on the energy facilities of traditional primary energy resources with carbon content. These products include $\mathrm{CO}, \mathrm{CO}_{2}$, methane $\left(\mathrm{CH}_{4}\right)$ as well as nitrous oxide $\left(\mathrm{N}_{2} \mathrm{O}\right)$, ozone $\left(\mathrm{O}_{3}\right)$, halocarbons $(\mathrm{CFC})$ and others gases called greenhouse. The consequence of the continuing increase in the Earth's temperature (global warming) is the change in the climate of our planet. It is accompanied by the numerous extreme natural (earthquakes, floods, hurricanes, etc.) and ecological (showers, thunderstorms, typhoons, etc.) events with the related economic and often fatal losses [2].

The anthropogenic changes are caused by the human activity to create industrial and infrastructure facilities including living quarters and communication systems that determine the interrelations between them. As applied to the purpose of our research, the main forms of modern settlements are large agglomerations located currently in vast areas.

Since 2010 most of the world's population has been living in the cities accounting for $75 \%$ of global energy consumption and $80 \%$ of $\mathrm{CO}_{2}$ emissions [3]. According to [4], in the next 40 years as many new cities will be build in the world as were erected since the beginning of the history of mankind. In Russia according to the Federal State Statistics Service [5] 109 million (74\%) out of 146.8 million people currently live in the cities. The number of the cities is growing rapidly every year which requires new approaches to the organization of their energy supply. Although cities account for only $2 \%$ of the Earth's surface, the urban areas are growing rapidly.

The greatest changes in recent years have occurred in the technological sphere of the world economy creating the production means and process management including the energy production. The new technologies of production, distribution and consumption of electric and thermal energy are constantly emerging or their existing types are being improved. If in the 19th century the steam technologies were innovative, in the 20th century electrical, then in the 21 st century the nuclear technique is innovative as well as the technologies using renewable energy sources and smart technique of the production process management.

The social demands of energy consumers have an essential role in the technological development of the world electric power industry to improve the social security of the provided energy services (excluding harm to health, increasing comfort, house coziness and quality of life).

The set of changing factors also determines the need for constant adaptation of technologies and quality of energy services provided by the domestic electricity industry which is really happening now but too slowly and not in all its functional areas. One of the most important areas of the domestic electric power industry is the heat supply system. This system was created in the country about 100 years ago and has not changed. The traditional system of water heat supply is based on the combined production of heat and electricity at the cogeneration plant. It was economically justified in our country in the thirties of the last century due to the technical advantages of steam technology over electrical at that time and failure to account the costs of withdrawn urban areas for infrastructure facilities of the production and transmission of thermal energy which then did not have a market assessment. However the situation in the country has changed significantly now, so there is a need to implement another concept for supplying consumers with the heat based on the use of electric energy or the new electric heat supply system $[6,7,8]$. 
The reasons for interest in the new electric heat supply system are the following objective tendencies occurring in the world and in our country:

- There is an increase in winter and summer temperatures in many regions of the country as a result of global warming. It reduces the need for heat energy in winter and conversely increases the need for electricity in the summer for air conditioning in the office and residential premises. For example, in recent years in St.Petersburg in the winter the air temperature has often risen to plus and in the summer reached $30 \div 35^{\circ} \mathrm{C}$. The similar situation is observed in other regions of the country.

- The reduction of heat demands in the country is due to the implementation of Federal Law №261, the energy saving and energy efficiency programs as a result of measures taken to prevent climate change $[9,10]$. The existing system of water heating is also a very energy-intensive sector of the economy. It consumes about $40 \%$ of the energy resources used in the country and accordingly it has a great potential for energy saving [11].

- There is a significant increase in the cost of land in megacities and large cities and increase in the density of their buildings. This complicates the allocation of sites for the creation of appropriate infrastructure facilities for development of the traditional heat supply systems [12].

- The structure of generating capacities in the world and in our country is also changing significantly. The largest increases are in the power plants using environmentally friendly (nuclear power plants) and renewable primary energy resources (hydropower plants, power plants using wind and solar energy, other clean sources).

- The requirements of energy consumers are increasing for the qualitative characteristics of energy supply systems and their energy services: reliability, safety, flexibility and comfort. The electric energy has significant advantages over thermal energy due to its absolute divisibility, instantaneous transmission for any distance and efficiency of use.

- The market of new technologies for production and use of electricity is emerging rapidly as a result of the growing demands of consumers for the qualitative characteristics of energy services and the advantages of electricity over thermal energy. The new technologies include solar collectors, electric storage devices, infrared heaters (IR panels), electric heaters, electric vehicles (the number of EVs in the world has already exceeded 2 million units according to the data of International Energy Agency [13]), smart technologies for production management and energy consumption, etc. [7, $14]$.

- The possibility of using market relations is of great importance in the preference of the new electric heat supply system to the traditional one which is almost completely excluded in the existing water heating system.

\section{Materials and methods}

The materials for conducted research of the two heat supply systems are the actual parameters of traditional and alternative water heating systems and the consequences of their use in the technological and economic fields as well as the impact on environmental performance.

The considered objective tendencies of development of the world and national economy determine the possibility of receiving many other essential advantages of the new electric heat supply system over traditional water heating system that is visible from Table 1 . It provides a comparison of their qualitative technical and economic characteristics. The analysis of Table 1 shows that the existing water heating system in the country has only one significant advantage over the new electric heat supply system. This advantage consists in 
the higher efficiency of production of two types of energy at the cogeneration plant but it is leveled by a whole set of its shortcomings. It does not allow consider the traditional heat supply system meets modern requirements of energy efficiency, environmental safety, accessibility and comfort of the provided energy services with the exception of heat supply in some isolated regions $[15,16]$.

The new electric heat supply system has, on the contrary, considerably larger set of technological, economic and social advantages compared to the traditional one and the only two drawbacks: higher primary energy costs for electricity generation at the condensing power plants and non-use of thermal energy losses with the exhaust gases and condensate.

Table 1. Comparison of the technical and economic qualitative characteristics of the traditional water heat supply system and the new electric heat supply system.

\begin{tabular}{|c|c|c|c|}
\hline \multicolumn{2}{|c|}{ Traditional water heat supply system } & \multicolumn{2}{|c|}{ New electric heat supply system } \\
\hline Advantages & Disadvantages & Advantages & Disadvantages \\
\hline $\begin{array}{l}\text { 1. High } \\
\text { efficiency of } \\
\text { electricity } \\
\text { and heat } \\
\text { energy } \\
\text { generation } \\
\text { in combined } \\
\text { production at } \\
\text { cogeneration } \\
\text { plant. } \\
\text { 2. Practically } \\
\text { the only } \\
\text { source of } \\
\text { electricity } \\
\text { and heat } \\
\text { production } \\
\text { for the } \\
\text { isolated } \\
\text { areas. }\end{array}$ & $\begin{array}{l}\text { 1. Inconsistency between } \\
\text { the thermal and electric } \\
\text { capacities of the } \\
\text { cogeneration plans to the } \\
\text { ratio of the thermal and } \\
\text { electrical loads of } \\
\text { consumers (for the central } \\
\text { part of Russia household } \\
\text { winter thermal and electrical } \\
\text { loads are in the ratio of } 3: 1 \\
\text { but the ratio of cogeneration } \\
\text { plant with CCGT unit } \\
\text { capacities is 1: 1). } \\
\text { 2. Dependence of the } \\
\text { efficiency of the } \\
\text { cogeneration plant operation } \\
\text { on the heat load. } \\
\text { 3. Discrepancy between the } \\
\text { demand curves for electric } \\
\text { and heat load. } \\
\text { 4. Excessively high } \\
\text { temperature of the heat } \\
\text { carrier in comparison with } \\
\text { its demand. } \\
\text { 5. High losses in the } \\
\text { transmission of heat energy. } \\
\text { 6. Low reliability of thermal } \\
\text { energy transmission system } \\
\text { (frequent winter accidents } \\
\text { on heat pipelines). } \\
\text { 7. High operation costs of } \\
\text { maintenance of the } \\
\text { infrastructure of the heat } \\
\text { supply system. }\end{array}$ & $\begin{array}{l}\text { 1. No need to use the } \\
\text { cogeneration and boiler plants } \\
\text { (except for isolated areas). } \\
\text { 2. Ability to align the daily and } \\
\text { seasonal load curves. } \\
\text { 3. Reducing the need for the } \\
\text { peak and reserve capacities. } \\
\text { 4. Reduction of the investments } \\
\text { in transport infrastructure } \\
\text { through the use of the same } \\
\text { electrical networks. } \\
\text { 5. Improving the reliability of } \\
\text { energy supply and reducing the } \\
\text { energy losses. } \\
\text { 6. Increasing incentives to use } \\
\text { other primary energy resources } \\
\text { in the electricity generation in } \\
\text { power systems. } \\
\text { 7. Reduction of investments in } \\
\text { newly constructed condensing } \\
\text { power plants due to the } \\
\text { simplification of their structure. } \\
\text { 8. Improving the ecological } \\
\text { safety of the region. } \\
\text { 9. Increasing the possibility of } \\
\text { introducing market relations } \\
\text { (competition, etc.). } \\
\text { 10. Improving the overall } \\
\text { efficiency of the system of } \\
\text { electric heat supply due to the } \\
\text { systemic effect of the listed } \\
\text { advantages. } \\
\text { 11. Increasing of energy } \\
\text { consumers' loyalty due to } \\
\text { better energy services. }\end{array}$ & $\begin{array}{l}\text { 1. Decrease in } \\
\text { the efficiency } \\
\text { of electricity } \\
\text { generation at } \\
\text { the condensing } \\
\text { power plant. } \\
\text { 2. Presence of } \\
\text { losses of the } \\
\text { thermal energy } \\
\text { with exhaust } \\
\text { gases and } \\
\text { condensate. }\end{array}$ \\
\hline
\end{tabular}

However the first drawback can be smoothed out by the above-mentioned advantages of the new electric heat supply system as well as the use of clean electricity generation technologies. The second drawback can be eliminated through the use of outgoing thermal energy on agricultural farms growing agro products in their own station areas or the areas located near commercial agricultural enterprises which already takes place in practice. 
Therefore the proposed new electric heat supply system meets the requirements of sustainable development: high energy efficiency, energy and environmental safety, accessibility and comfort of energy services.

\section{Results and discussion}

Let us show the quantitative advantages of the new electric heat supply system over the traditional system of water heating on the example of the development of a large city $\mathrm{N}$ with the parameters of its prospective heat and power consumption shown in Table 2 . It is assumed in the calculation that during the forecast period 2020-2035 in each subsequent five-year forecasted demand for thermal energy will be $25 \%$ replaced by electricity at a ratio of $1 \mathrm{Gcal}=1.163 \mathrm{MWh}$ [6]. It is also accepted that the losses in the transmission of heat energy together with the own needs are $18 \%$ and in the transmission of electricity $12 \%$. According to the Ministry of Energy of Russian Federation the total losses in thermal facilities and pipelines can reach $30 \%$ [11]. We assume in addition that with the new system of electric heat supply the demand for heat will decrease by $30 \%$ due to more efficient air temperature control and the exclusion of the open vents effect in homes and offices as well as winter breakthroughs of hot water in heating pipelines.

The comparison of the calculated parameters of the traditional and new electric and heat consumption system is given in Table 2 . It shows that the transition of a large city $\mathrm{N}$ to a new electric heat supply system during the forecast period will require an additional $16 \mathrm{GW}$ of new electric capacity and refuse to put into service $11,200 \mathrm{Gcal} / \mathrm{h}$ thermal capacity at the cogeneration or boiler plants. That means the need to build additionally four new condensing power plants with an installed capacity of $4 \mathrm{GW}$ each to cover the increase of the electric load and to abandon the construction of 5-6 cogeneration plants with capacity from 2,000 to $2,500 \mathrm{Gcal} / \mathrm{h}$ each to cover the increase of thermal loads.

Table 2. Actual and forecast values of the consumption/generation of electric and thermal energy of the city $\mathrm{N}$ during 2020-2035 at the traditional (numerator) and the new electric heat supply system (denominator).

\begin{tabular}{|c|c|c|c|c|c|}
\hline Parameters & 2017 & 2020 & 2025 & 2030 & 2035 \\
\hline $\begin{array}{c}\text { Electricity consumption, } \\
\text { bln kWh } \\
\text { Electricity generation, } \\
\text { bln kWh } \\
\text { Installed electric power, } \\
\text { GW } \\
\text { Thermal energy consumption, } \\
\text { mln Gcal } \\
\text { Thermal energy production, } \\
\text { mln Gcal } \\
\text { Installed heat capacity, } \\
\text { thnd Gcal/h }\end{array}$ & $\begin{array}{c}5.7 \\
44.0 \\
44.9\end{array}$ & $\begin{array}{l}\frac{27.9}{42.0} \\
\frac{31.2}{47.0} \\
\underline{6.9} \\
8.5 \\
\underline{50.6} \\
\frac{59.0}{44.8} \\
\frac{16.4}{12.3}\end{array}$ & $\begin{array}{l}\frac{31.4}{54.2} \\
\frac{35.2}{60.7} \\
\underline{7.8} \\
11.1 \\
\frac{56.8}{28.4} \\
\frac{67.0}{33.5} \\
\frac{18.4}{9.2}\end{array}$ & $\begin{array}{l}\frac{36.1}{75.1} \\
\frac{40.4}{84.1} \\
\underline{9.0} \\
15.3 \\
\frac{64.0}{16.0} \\
\frac{75.5}{18.9} \\
\frac{20.7}{5.2}\end{array}$ & $\begin{array}{l}\frac{40.6}{109.2} \\
\frac{45.5}{122.3} \\
\frac{10.1}{22.2} \\
\frac{72.0}{0.0} \\
\frac{85.0}{0.0} \\
\frac{23.4}{0.0}\end{array}$ \\
\hline
\end{tabular}

Note: it is assumed assessing the installed electric power that the number of hours of its use increases from 4,500 to 5,500 hours per year due to alignment of load curves in the new electric heat supply system.

The comparison of technical and economic indicators of application of the traditional water heat supply system of the city $\mathrm{N}$ and the new electric heat supply system in the predicted period at the conditions specified above is given in Table 3 . It follows that the total operation costs under the new electric heat supply system are lower by 38.4 or 40.2 billion rubles per year respectively when burning coal or natural gas (about 10.5\%) even 
without taking into account many other advantages of the new and drawbacks of the traditional heat supply system of the city detailed in Table 1 .

Table 3. Comparison of technical and economic indicators of application of the traditional water heat supply system in the city $\mathrm{N}$ and the new electric heat supply system during 2020-2035.

\begin{tabular}{|c|c|c|}
\hline Indicators & $\begin{array}{l}\text { Traditional water heat } \\
\text { supply system }\end{array}$ & $\begin{array}{l}\text { New electric heat } \\
\text { supply system }\end{array}$ \\
\hline $\begin{array}{c}\text { The growth of new capacities } \\
\text { The need for new capacities and power } \\
\text { plants }\end{array}$ & $\begin{array}{c}11,200 \mathrm{Gcal} / \mathrm{h} \text { of heat load } \\
5 \text { cogeneration plants heat } \\
\text { capacity } 2,500 \mathrm{Gcal} / \mathrm{h} \\
\text { each }\end{array}$ & $\begin{array}{l}16 \mathrm{GW} \text { of electric load } \\
4 \text { condensing power } \\
\text { plants installed electric } \\
\text { power } 4 \mathrm{GW} \text { each }\end{array}$ \\
\hline $\begin{array}{l}\text { The need for investment including } \\
\text { transport infrastructure, bln rubles } \\
\text { Fuel consumption for energy }\end{array}$ & 1,200 & 800 \\
\hline $\begin{array}{l}\text { production, mln tons of coal equivalent } \\
\text { per year }\end{array}$ & $20.1^{*}$ & 26.4 \\
\hline $\begin{array}{l}\text { The cost of fuel spent, bln rubles } \\
\text { per year }\end{array}$ & 120.5 & 158.4 \\
\hline $\mathrm{CO}_{2}$ emission, mln tons per year & $\frac{4.62 * *}{2.82}$ & $\frac{6.07}{3.56}$ \\
\hline $\begin{array}{l}\text { The cost of } \mathrm{CO}_{2} \text { emissions, bln rubles } \\
\text { per year }\end{array}$ & $\frac{11.55^{* *}}{7.05}$ & $\frac{15.2}{8.9}$ \\
\hline $\begin{array}{l}\text { Constant costs for energy production, } \\
\text { bln rubles per year }\end{array}$ & 240 & 160 \\
\hline $\begin{array}{c}\text { Total operation costs, bln rubles } \\
\text { per year }\end{array}$ & $\frac{372.0^{* *}}{367.5}$ & $\frac{333.6}{327.3}$ \\
\hline
\end{tabular}

* taking into account the operation of each 1,200 MW cogeneration plant in the condensation regime for 6 months a year with the power factor equal to 0.57 .

** burning coal (numerator) and natural gas (denominator).

Among the most significant disadvantages of the traditional water heat supply system are such as the need for the preferential location of the cogeneration plant directly on the territory of the city or the nearest suburbs. The consequences are their pollution by liquid, solid and gaseous emissions (Table 4) as well as the high accident rate of heat pipelines with the corresponding huge annual economic and even fatal losses. According to [11], on each $100 \mathrm{~km}$ of heat pipelines on average 70 damages are annually registered.

Therefore, it is not accidental that in the Global Liveability Report 2017 [18] annual rating of the world's most liveable cities St. Petersburg took only 77th and Moscow 80th place out of 140 possible while St. Petersburg in this rating was higher than other Russian cities. According to the Economist Intelligence Unit methodology, the key parameters determining the quality of life in the world's cities were the state of the health system, ecology, stability, culture, education system and infrastructure. The cities of Melbourne, Vienna and Vancouver ranked first, second and third places respectively.

In the similar annual ranking of the world's countries in terms of living standards, The Legatum Prosperity Index 2017 [19] Russia was on the 101st place among 149 countries and the 1 st place was taken by Norway.

Among the key parameters taken into account in this rating also appear the level of ecology according to which Russia was on the 56th place; the economic indicators - 70th; the state of the business environment -85 th; the effectiveness of governance -115 th; the quality of education -26 th; the quality of health care $-102 \mathrm{nd}$. 
Table 4. The consumption of resources of different types and release of hazardous waste in the production of electrical and thermal energy at condensing and cogeneration power plants.

\begin{tabular}{|c|c|c|}
\hline Type of resource or waste & $\begin{array}{c}\mathbf{1 , 0 0 0} \mathbf{~ k W h} \text { of electricity } \\
\text { production }\end{array}$ & $\begin{array}{c}\mathbf{1 , 0 0 0} \text { Gcal of thermal } \\
\text { energy production }\end{array}$ \\
\hline Fuel, tons of coal equivalent & $0.28 \div 0.34$ & $12 \div 30$ \\
Fresh water, cubic meters & $100 \div 125$ & $130 \div 160$ \\
Alienation of land, hectares & $0.4 \div 1.0$ & $0.8 \div 2.5$ \\
Solid waste, tons & $0.2 \div 0.5$ & $0.18 \div 0.40$ \\
Discharge of contaminated sewage, & 0.5 & 0.7 \\
$\begin{array}{c}\text { cubic meters } \\
\mathrm{CO}_{2} \text { emissions from combustion of } \\
\text { coal, tons }\end{array}$ & & \\
natural gas, tons & $0.21 \div 0.25$ & $0.24 \div 0.29$ \\
\hline
\end{tabular}

Compiled from [2, 17].

With the ongoing climate change on Earth the environmental performance of countries and their cities is now no less important than political issues. Today humanity faces two alternative strategies for the development of large cities and megacities: to copy existing strategies with their numerous problems (dirty air, difficulties for life, etc.) or to develop a new concept of smart sustainable cities and new low-carbon infrastructure. The concept of smart sustainable cities is based on the full-scale use of the potential of information and communication technologies in urban management systems for the creation of cities that not only have a modern socio-economic sphere but are also created with a view to ensure environmental sustainability [20].

According to [4], the new infrastructure of smart cities based on electricity production using renewable energy sources is only $4 \%$ more expensive, but such overpayment pays off for about 2-3 years. The proposed new electric heat supply system is more suitable for the construction of smart sustainable cities as well as for the creation of modern innovative economy based on sustainable development. The main parameters of smart sustainable cities are energy and environmental security due to the numerous advantages of electric energy over thermal energy (absolute divisibility, instantaneous long-distance transmission, high efficiency of use, ecological friendliness, etc.).

\section{Conclusions}

According to the results of work, the new electric heat supply system is very effective for the majority of Russian cities. Its implementation should be started from megacities and major industrial centers, the size of the territories of which has been increasing rapidly in recent years.

The research has showed the significant advantages of the new electric heat supply system. The proposed system meets the requirements of sustainable development of Russian cities, provides the high level of competitiveness of their production systems and contributes to the preservation of the health of their residents.

\section{References}

1. Global Climate Observing System, WMO, https://public.wmo.int/en/ programmes/global-climate-observing-system

2. M.P. Fedorov, V.R. Okorokov, R.V. Okorokov, Energeticheskie tekhnologii i mirovoe ekonomicheskoe razvitie: proshloe, nastoyashchee, budushchee (Nauka, St.Petersburg, 2010) 
3. Intellektual'nyy podkhod i perspektivy ustoychivogo razvitiya gorodov, Intelligent Energy CIS, 6 (2012)

4. Zh.P. Trikuar, Vedomosti, 3884 (2015)

5. Russian statistical yearbook 2017, http://www.gks.ru/bgd/regl/b17_13/main.htm

6. V. Dzhangirov, N. Lelyushkin, V. Maslov, Energorynok, 2(74) (2010)

7. O.P. Lyulehkin, S.O.K., 2 (2013)

8. V.R. Okorokov, R.V. Okorokov, ISPU Vestnik, 6 (2015)

9. Federal law of the Russian Federation №261-FZ of 23.11.2009

10. The state program of the Russian Federation №2446-r of 27.12.2010, http://legalacts.ru/doc/rasporjazhenie-pravitelstva-rf-ot-27122010-n-2446-r/

11. Kontseptsiya teplosnabzheniya v Rossii, vklyuchaya kommunal'nuyu energetiku, na srednesrochnuyu perspektivu (The Ministry of Energy of the Russian Federation, Moscow, 2002)

12. N. Verstina, E. Evseev, MATEC Web of Conferences 106, 08090 (2017)

13. World Energy Outlook 2017, IEA, http://www.iea.org/textbase/npsum/ weo2017SUM.pdf

14. R.V. Okorokov, A.V. Zadorozhniy, Jeffektivnost' primenenija intellektual'nyh tehnologij $v$ otechestvennoj jenergetike (Publishing of Polytechnic University, St.Petersburg, 2015)

15. V.R. Okorokov, R.V. Okorokov, Akademiya energetiki, 6(62) (2014)

16. V.I. Velkin, WIT Transactions on Ecology and the Environment 1, 190 (2014)

17. M.P. Fedorov, V.I. Maslikov, Razvitie elektroenergetiki i okhrana okruzhayushchey sredy (Publishing of Polytechnic University, St.Petersburg, 2002)

18. The Global Liveability Report 2017, EIU, http://www.eiu.com/public/thankyou_ download.aspx?activity=download\&campaignid=Liveability 17

19. The Legatum Prosperity Index 2017, LIF, https://li.com/activities/publications/ the2017-legatum-prosperity-index

20. Building tomorrow's Smart Sustainable Cities, ITU News, 2 (2016) 